\title{
Aggravating Circumstances. Significance and Correlation with Qualifying Signs
}

\author{
Larisa V. Gorbunova \\ Ruslan V. Makarov \\ Sergei A. Matveev \\ Mari State University, Yoshkar-Ola, Russia \\ Email:pvl_mksv@mail.ru
}

Doi:10.5901/mjss.2015.v6n3s7p169

\begin{abstract}
The article explains the aggravating circumstances concept and essence. It shows the correlation between the aggravating circumstances and qualifying signs of crimes and examines the role of aggravating circumstances in sentencing under the Criminal Code of the Russian Federation. The qualifying signs and the aggravating circumstances are treated ambiguously in the doctrine of criminal law. The monographic study of these criminal law institutions in Russia have been carried out on the basis of the voided penal legislation. The analysis of the aggravating circumstance and qualifying signs of the crimes in this article has been done following the latest changes in the criminal legislation of the Russian Federation. During the study of these criminal responsibility differentiation means and punishment individualization 1,000 criminal cases has been studied. Also the mistakes made by the courts using qualifying signs and aggravating circumstances were revealed. The recommendations to improve judicial practice and criminal law were made in this paper based on an analysis of judicial practice. In addition, a comparative analysis of the criminal punishment institution under the Criminal Code of the Russian Federation and the Italian criminal law has been performed.
\end{abstract}

Keywords: qualification of crimes, sentencing, aggravating circumstances, judicial errors.

\section{Introduction}

Many institutions of criminal law are significantly updated or changed in the Criminal Code of the Russian Federation. The changes have been made in the provisions relating to the aggravating circumstances. The titles of the examined cases and the wording of some aggravating circumstances are changed and the new species of them are added into the Criminal Code of the Russian Federation.

The aggravating circumstances of the criminal law of Russia has been already studied (Bazhanov, 1974, Galperin, 1986, Ivanov, 1970, Ishchenko, 2002, Karpets, 1959, Kozlov, 1977, Krieger, 1980, Kruglikov, 1977, Myasnikov, 2002, Stanovsky, 1999).

However many scientific principles and recommendations contained in the works of these authors have been prepared on the legal framework of the voided legislation. The foregoing underlines the necessity of the scientific apprehension of modern approaches to the problem of aggravating circumstances based on the analysis of the sentencing judicial practice.

A list of aggravating circumstances is set in the paragraph 1 article 63 of the Criminal Code of the Russian Federation, 1996. The following circumstances are recognized as aggravating: a) recidivism; b) occurrence of serious consequences in a result of the crime; c) commission of a crime by a group of individuals, by a group of individuals by prior conspiracy, by an organized group or criminal community (criminal organization); d) a particularly active role in the commission of a crime; e) involvement in the crime of persons who suffer from severe mental disorders or are in a state of intoxication, as well as persons who have not attained the age at which criminal liability accrues; f) commission of a crime by reason of national, racial or religious hatred or enmity or hatred or hostility toward a social group; f.1) commission of crime in revenge for lawful actions of other persons as well as to conceal another crime or facilitate its commission; g) the commission of a crime against a person or his relatives in connection with implementation of his professional or public duty; $h$ ) the commission of a crime against a pregnant woman when the pregnancy is known by the perpetrator, or against the child or another defenseless or helpless person, or a person who is dependent on the perpetrator; i) commission of a crime with particular cruelty, sadism, humiliation and torture of the victim; j) a crime 
involving weapons, ammunition, explosives, explosive or simulating them devices, specially manufactured technical means, narcotic drugs, psychotropic, strong, poisonous and radioactive substances, medicinal and other chemical and pharmaceutical products, as well as the use of physical or mental coercion; k) commission of a crime in case of emergency, natural or other public disaster, as well as the riots; l) commission of a crime with the use of trust granted to the perpetrator by virtue of his official position or contract; $\mathrm{m}$ ) commission of a crime using a uniform or documents of a government representative; n) committing an intentional crime by the officer of the internal affairs department; 0 ) commission of a crime against a child by a parent or other person legally responsible for the upbringing of a child, as well as pedagogical staff or other employee of an educational organization, medical organization, an organization that provides social service, or other organization, obligated to supervise the child; $p$ ) the commission of a crime in order to promote, justify and support terrorism. According to the paragraph 2 article 63 of the Criminal Code of the Russian Federation when the judge (the court) imposes the penalties depending on the nature and degree of social danger of the crime, the circumstances of its commission and the identity of the perpetrator, he may recognize the aggravating circumstances of the crime the fact that the person has committed a crime in the state of intoxication caused by alcohol, narcotics or other intoxicating substances.

In the theory of the criminal law and legislation the circumstances provided now in the part 1 article 63 of the Criminal Code of the Russian Federation were called in different ways for example "influencing the degree of guilt" (Bazhanov, 1974), "maximizing the guilt" (Isayev, 1948), "aggravating the offense" (Demidov, 1964), "aggravating the public danger" (Karpets, 1959), "aggravating the degree of responsibility" (Fatkullin, 1974).

We believe that it is incorrect to call aggravating the circumstances listed in paragraph 1 article 63 of the Criminal Code of the Russian Federation. The presence of aggravating circumstances indicates a greater degree of a social danger of the offense and the personality of the offender, but not the greater degree of his guilt. Since the degree of the offender's guilt should not be determined by the set of all circumstances of the crime, but only by the mental attitude of the perpetrator to the offence and by the nature of this mental attitude.

It is difficult to agree with the authors who call the examined circumstances aggravating the crime, public danger or responsibility. This kind of titles do not reflect the essence and mission of the aggravating circumstances which is namely to enhance the punishment. In this sense, the position of the legislator, currently considering these circumstances as circumstances aggravating the punishment, should be regarded as justified.

The term "aggravating circumstances" is used in the doctrine and the practice as the characteristic of the circumstances referred to in the article 63 of the Criminal Code of the Russian Federation, and the characteristic of certain qualifying circumstances of the offense.

Practitioners as well have no clear understanding of the difference between the qualifying circumstances (signs) and aggravating circumstance.

Any sign that is used to construct the species of different offenses by the legal nature is considered to be a mitigating or aggravating circumstance (for example, a group of persons committing a crime, etc.) (Kostareva, 1993). However, sometimes the features that can not be attributed to the mitigating or aggravating circumstances are used during the formation of the basic structure. Almost every second article of the Special Part of the Criminal Code of the Russian Federation refers to a one or a few species of composition, and each of these species includes, as a rule, a number of alternative characters. That is why the number of aggravating circumstances is comparable to the number of essential elements of offenses contained in the Special Part of the Criminal Code of the Russian Federation. This implies that the opposition of the main elements of the crime to the qualified signed is unsuccessfully called "aggravating circumstances" (Buranov, 2002). It leads to the confusion and fuzzy understanding of the "aggravating circumstances" concept and also the "qualified crime components" concept in the theory and practice of criminal law.

In order not to confuse the aggravating and the qualifying circumstances of the offense the term "aggravating circumstances" should be used only in reference to the circumstances listed in paragraph 1 article 63 of the Criminal Code of the Russian Federation.

In order to properly disclose the substance of aggravating circumstances it is necessary, first of all, to distinguish them from the qualifying signs of the offense.

The qualifying signs of the offence are typically specified in second (third, etc.) parts of the articles in the Criminal Code of the Russian Federation. They carry out a specific function: they lead to the creation of a variety of crimes, and, consequently, to the emergence of new sanctions which usually result in the more severe punishment. Thats why these types of circumstances are called in the literature special (or qualifying) circumstances (Kostareva, 1993).

Kruglikov L.L. rightly pointed out that in contrast to the qualifying signs the aggravating circumstances mentioned in the General Part of the Criminal Code of the Russian Federation do not refer the circumstances of the offense. They lie outside of the offence and therefore are not able to influence the determination of the formalized framework of 
punishment for a certain type of crime. They do not involve the establishment of a new "typical" punishment or other sanction. Such circumstances can only change the extent of criminal law sanctions within the sanction set in the article, to influence the selection of a particular type and size of the punishment by the court within the definition of "typical" punishment (Kruglikov, 1977).

Therefore the qualifying circumstances and the aggravating circumstances of the offense influence the type and the size of the punishment (Klenova, 2001). However, their legal nature differs significantly.

The aggravating circumstances provided in the part 1 of article 63 of the Criminal Code of the Russian Federation are inherently the circumstances which the legislator enforces to influence the sentence selected by the court making it more severe.

The comparison of the qualifying circumstances of the crimes which are set in the Special Part of the Criminal Code of the Russian Federation with the aggravating circumstances listed in part 1 of article 63 of the General Part of the Criminal Code of the Russian Federation allows us to specify a match of some of them by name (for example, such as a crime committed by a group of persons acting in collusion with the use of weapons, in a state of intoxication, and others). The use of the same wording in the Criminal Code of the Russian Federation, the coincidence describing the qualifying circumstances and aggravating circumstances gives a rise to the idea of the unity of their legal nature.

As a result some criminologists have concluded that the aggravating circumstances and the qualifying signs are "the same" (Kostareva, 1993).

In consideration of legal phenomena you can really find a lot in common: these circumstances are beyond the scope of the main elements of a crime, they are closely related to the offense and with the personality of the perpetrator. These factors have an impact on the amount of criminal liability but for the content some types of these circumstances are the same.

However, the unification of these concepts is unacceptable. Aggravating circumstances serve as a means of the differentiation but not of the individualization of punishment, and they form an instrument in the hands of the legislature but not of the judge (Kostareva, 1993).

The influence of aggravating circumstances and qualifying signs on the type and size of the criminal punishment for the criminal actions are different. Qualifying sign (or some signs) of specific offenses is used in the law to construct the structure of the same crime, which is characterized with an increased danger to society and thereby entails the formulation of stricter sanctions in the relevant part of the article of the Russian Criminal Code. It constitutes a new ground of an increased criminal liability of the perpetrator. Committing a crime in the presence of qualifying signs does not form a new foundation of criminal responsibility and the court shall impose a sentence within the sanctions of the Criminal Code of the Russian Federation without aggravating circumstances.

On the contrary, committing a crime with an aggravating circumstance does not produce a different legal basis of criminal responsibility. When the court solves the issue regarding the criminal responsibility of the perpetrator the crucial will be the elements of a crime but not the aggravating circumstances. The court will sentence within the sanction stipulated in the article which contains the signs of a crime.

It is necessary to agree with the authors who insist on division of the aggravating and qualifying circumstances (Volzhenkin, 1987). A different view is held by I.M. Galperin who offers to unify qualifying and aggravating circumstances and to bring them into a single list (Galperin, 1986). For several reasons it is difficult to disagree with the judgments mentioned above.

Speaking of an inappropriate unification of qualifying circumstances and aggravating circumstances we should point out that the disappearance of the aggravating circumstances from the Criminal Code of the Russian Federation will impose a considerable damage to the organic nature and function of the mitigating circumstances provided for by part 1 of article 61 of the Criminal Code of the Russian Federation. In that case the mitigating circumstances will not be "equilibrate" with the aggravating circumstances. If the qualifying signs will be abolished, it seems unclear how the majority of the crimes will be considered as crimes of medium gravity, grave and especially grave crimes. In any case, these criteria are alien to the institute of the contemporary Russian criminal law.

\section{Materials and Methods}

We have made a distinction between the aggravating circumstance and the qualifying circumstances of the offense. Also we have analyzed the historical and contemporary literature, the Russian Criminal Code and previously valid criminal law, 1000 criminal cases materials.

The studies prepared by the authorities or public organizations were used in this paper.

The methodological basis of the study is the dialectical method of cognition which helps to reveal the institute of 
the aggravating circumstance and the qualifying circumstances of the offense in the development and in conjunction with the other institutions of the Russian criminal legislation, and also based on this method, the general scientific, special and private-research methods.

\section{Results}

It is necessary to disclose the nature of aggravating circumstances as a criminal-legal phenomenon by establishing the independence of the aggravating circumstance from the qualifying circumstances of the offense.

First of all it should be noted that the aggravating circumstances are the circumstances of the case. In this case, under the circumstances of the case we consider the things that are directly related to the features of the crime and the identity of the perpetrator of legal significance. That is impossible to relate the signs that are indifferent from the point of view of the features of the crime to the circumstances of the case even when they sometimes may have forensic value. However, not all facts of the case could be referred to the aggravating circumstances by the legislator though sometimes they can objectively influence the sentence. For example, the circumstances included as a positive sign of a crime can not be attributed to the aggravating circumstance.

The essence of aggravating and mitigating circumstances is ambiguously interpreted in the doctrine of the Russian criminal law. Karpets I.I. suggested that such circumstances "aggravate or mitigate socially dangerous acts" (Karpets, 1959).

This view was criticized by L.L. Kruglikov. He noted that such a controversial understanding of the nature of the mitigating and aggravating circumstances becomes apparent even by a cursory acquaintance with the ones that are listed in the General Part of the Criminal Code of the Russian Federation. So the sincere repentance and the acknowledgement of guilt can not affect the socially dangerous act, since the crime is already completed. Therefore it is better to study the investigated circumstances as factors related to a crime and (or) a personality of the perpetrator that characterize the greater or smaller social danger of the offense and the perpetrator or only his personality (Kruglikov, 1977).

This point of view can not be regarded as flawless because all aggravating circumstances affect the social danger of the act and the offender's personality to some extent. But precisely this feature of aggravating circumstance does not matter because it can not be regarded as distinctive.

It is important to be sure that the list of aggravating circumstance chosen by the legislator is not a result of a random sample of various circumstances which are not influenced by certain subjective opinions, views or opinions. And that it is based on the real objective reasons that give a reason to believe that any aggravating circumstances provided in subsection 1 of Article 63 of the Criminal Code of the Russian Federation was to be really established in accordance with the criminal law and have a significant impact on the assigned punishment. For this purpose the main criteria that characterize the essence of aggravating circumstances, the totality of which expresses their distinctive features, should be identified.

There are four criteria in the literature: 1) typification, 2) commitment, 3) significance and 4) the well-defined orientation.

1. The typical circumstances included in the Criminal Code are the specificity of more or less extensive range of offenses (Mikhlin, 1958). As a general rule, the typification characteristic (criterion) is the expansion of a particular circumstance. Prevalence of the aggravating circumstance involves on the one hand the fact that this circumstance does not occur only on one or two types of crime, as it is typical for many types of socially dangerous acts. And on the other hand, in the total weight of the crimes they can be seen very often. The proportion of the aggravating circumstance is big enough in the commission of crimes in comparison to all other circumstances. Therefore, if there is a question on the inclusion of specific circumstances in the list provided in part 1 of Article 63 of the Criminal Code of the Russian Federation. It is important to justify from the viewpoint of criminology.

The introduction of the non-typical circumstances to the list of aggravating circumstance leads to unjustified widening of that list. That fact complicates the implementation by the court (judge) of the criminal law requirements on taking into account the aggravating circumstances in sentencing.

2. The obligation of its influence means that the aggravating circumstance affects the level of social danger in all cases where it has taken place, regardless of the specific characteristics of the offense and the personality of the perpetrator. In other words, if the presence of aggravating circumstance is established in the case it means that the danger of this crime is bigger and the penalties for this crime should be more severe than for the act which would have been imposed in the absence of aggravating circumstances. Thus, the commission of a 
crime using a weapon (item "a" of part 1 of Article 63 of the Criminal Code of the Russian Federation) is always an evidence of the heightened social danger of the crime and the personality of the perpetrator and that it is therefore rightly included in the list of aggravating circumstances.

3. An important feature of the aggravating circumstances is a significant impact on the increasing of the gravity of the offense and consequently on the punishment. The measure of the effect of the aggravating circumstances must be taken into consideration by the court (judge) for the proper implementation of the law every time such a circumstances is found in the case. Moreover, the account of the aggravating circumstances might lead to a fairly significant increase in the severity of the form and size of a criminal punishment.

4. The effect of the aggravating circumstances must be strictly defined. This means that the aggravating circumstance specified in law is capable only to increase the social danger of the offense and the personality of the perpetrator. It should lead to the appointment of a more severe punishment. The strictly defined direction of influence is an essential criterion for distinguishing the aggravating and mitigating circumstances.

Thus, they can be defined based on the analysis of the main criteria for selection an aggravating circumstance. The aggravating circumstance are the facts, events, phenomena of objective and subjective nature, which characterize a fairly broad range of offenses and will certainly raise the degree of public danger of the offense, and (or) the personality of the offender. The direction of their influence can vary depending on any other circumstances of the case and therefore determines the feasibility of a more severe punishment within the criminal law sanctions.

The part 3 of Article 60 of the Criminal Code prescribes to consider the nature and degree of social danger of the crime and the personality of the perpetrator, including the aggravating and mitigating circumstances, as well as the influence of the appointed punishment on correction of the convict, and the living conditions of his family while sentencing. The same general rules for sentencing are provided in the penal codes of a number of foreign countries. In particular, the aticle 133 of the Italian Penal Code requires a judge in sentencing to take into account: the severity of the offense; the severity of the harm or danger to which the victim was subjected to; the intensity of the intention or degree of negligence; criminal motives and character of the offender; previous involvement in criminal and other legal liability, lifestyle of the defendant; behavior at the time and after the commission of the offense; personal, family and social conditions of the defendant. Thus, a law proclaiming the principle of the free discretion of the judge when sentencing detail points to the objective and subjective circumstances which the court is obliged to assess when choosing penalties in each case.

The types of mitigating and aggravating circumstances are set in paragraph 1 of Article 61 and 63 of the General Part of the Criminal Code of the Russian Federation. This is connected to the fact that the criminal law gives a special role to the mitigating and aggravating circumstances.

The study of the part 1 of Article 63 of the Criminal Code of the Russian Federation lids to the following conclusions on the aggravating circumstances:

a) the record of the aggravating circumstances, as well as the data on the personality of the perpetrator, the nature and degree of public danger of a crime is a mandatory element of individualization of the punishment and it is therefore the duty of the court (judge);

b) the data on the personality of the offender, the nature and degree of social danger of the crime which are essential for the individualization of punishment are not confined to those aggravating circumstances listed in the criminal law;

c) the aggravating circumstances do not characterize the offender's personality and the nature and degree of social danger of the crime, and the increase of social danger of the committed crime and the personality of the perpetrator and involve the appointment of a more severe punishment (Melnikov, 1989).

In the scientific literature the question of the correlation between the aggravating circumstance and other selection criteria of criminal law is also debatable.

It should be noted that the aggravating circumstances as the data in whole or in part characterizing the social danger of the crime and the personality of the perpetrator can lead to the fact that the court would equate any even the smallest details of the gravity of the offense and the personality of the offender to the aggravating circumstance. Meanwhile the special status of the aggravating circumstances and the impact of each of these circumstances on the assigned punishment is higher than that of all the circumstances characterizing the social danger of the crime or the personality of the perpetrator. Otherwise the allocation of some of the circumstances in the separate list provided in Article 63 of the Criminal Code of the Russian Federation does not make sense.

In the process of classification of the offense and at the first stage of individualization of punishment the role of aggravating circumstances is not shown.

Attributing a particular offense to a particular category of severity the legislator indicates its obligatory 
characteristics in the Criminal Code of the Russian Federation. Their volume can not be increased by taking into account the aggravating circumstances otherwise an incorrect legal assessment of the act will be given. The differentiation of the criminal responsibility is usually processed by the qualification of the crime. Establishment of mandatory attributes provided by the criminal law (corpus delicti) in the perpetrator's act serves as the basis for identifying the scope of liability incurred by the offender. This volume is a common responsibility for all the crimes that may contain the same crime. Independent from the subject and the circumstances under which he has committed a crime such crime must qualify for the article of the Criminal Code of the Russian Federation. That provides indications of the composition of the crime. Depending on the specific circumstances of the case such as aggravating circumstance it is impossible to change the qualification of the offense. And therefore the question of the possible form and amount of punishment can't be prejudged. The difference in punishment for the crime is defined not by the equal legal assessment act but those criteria which are set in Part 3 of Article 60 of the Criminal Code of the Russian Federation.

The punishment can not be applied if the person's actions do not constitute a crime. Therefore, the composition of a crime and the punishment are interconnected as a disposition and a sanction. The sanction of an article usually contains the type and size of penalties for the offense, described in the disposition of the article. But the sanction prescribing the punishment for certain socially dangerous act sometimes has a rather broad limits. The court also must always impose and individual punishment (Karpets, 1959).

The basis for the individualization of punishment are the aggravating circumstances. Aggravating circumstances are strictly defined by the law and their effects can not be mixed with the influence of other circumstances affecting the assigned punishment. According to Paragraph 2 of Article 63 of the Criminal Code of the Russian Federation if an aggravating circumstance is provided by appropriate article of the Criminal Code as an offense in itself it can not be reconsidered in sentencing. However, it is necessary to substantiate the theory as an opposite point of view can be found in the scientific literature.

Many authors put in a basis of classification of aggravating circumstances the ratio of the nature and degree of social danger of the crime, the personality of the perpetrator and the aggravating circumstances. All judgments combine two scientific positions on this issue. For example, some authors offer aggravating circumstances to be classified into two groups: 1) the first group characterizes the degree of social danger of the crime and 2) the second one characterizes the perpetrator's personality (Tkachenko, 1997). Some authors consider it appropriate to share all aggravating factors into three groups: 1) the facts relating to the objective and subjective characteristics of the socially dangerous act; 2) the circumstances relating to the personality of the subject, and 3 ) the circumstances relating to the causes and conditions which are associated with this criminal act (Anashkin, 1980).

The said classifications are vital but at the same time they are conditional. It is impossible to categorize the relevant circumstances into certain groups for the purpose of punishment individualization. The same circumstances and at the same time can characterize the offense and the offender as personal peculiarities manifest in behavior. In addition, the assignment of a particular circumstance to the individual elements of the offense, as a rule, does not contribute to clarification of the content and meaning of each aggravating circumstance. Many of them simultaneously characterize both objective and subjective characteristics of the crime.

The Russian criminal law theory protects a judgment of a possibility to take into account the negative information on the perpetrator's personality in personalization of the punishment. Such information is not included in the list of aggravating circumstances (Melnikov, 1989).

This point of you is arguable. If there is no difference between the guilt's personality and aggravating circumstances than there is no meaning in a list of aggravating circumstances existing in the Criminal Code of the Russian Federation. Giving the list of aggravating circumstance an open nature would negate the efforts of legislator to form this list. Moreover a broad interpretation of the list of aggravating circumstance results in a divergent jurisprudence in which some courts will consider an aggravating any specific circumstances of the case, while others will not.

The registration of other data, such as previous convictions, can be also identified as the means of individualization of punishment in addition to the aggravating circumstances. In its decision dated December 23, 2014 the Constitutional Court of the Russian Federation assigns that in its nature the institute of criminal record as a means of criminal law is aimed to ensure the constitutional principle that the law applies to everyone without discrimination in the field of criminal law and it is aimed to achieve a constitutionally significant goals of differentiation of criminal liability and punishment, enhancement its correctional impact on the convict, prevention of new crimes and thus it provides the protection of individuals, society and the state from criminal attacks. In the Criminal Code of the Russian Federation the penal consequences of the criminal record do not go beyond the means of the criminal law that the federal legislator may use to achieve these goals (Baskakova, Gabdrahmanov, Gorbunova, Smirnov, 2014).

Such circumstance as a crime committed in a state of intoxication caused by alcohol, drugs or other intoxicating 
substances is nowadays ambiguously estimated by the court due to the changes in Article 63 of the Criminal Code of the Russian Federation. Pursuant to Part 1.1 of the Article 63 of the Criminal Code of the Russian Federation, the court has the right according to the nature and degree of social danger of the crime to recognize the circumstances of its commission and the personality of the perpetrator as aggravating or not. This legislative innovation is the first step towards giving the list of aggravating circumstance an open character and it is one of the latest example of the judicial discretion expansion.

There are indications registered as aggravating circumstance, such as "non-recognition of guilt and convicted uncompensated damage," "lack of remorse and regret about what happened from a convict" in the court verdicts. The Supreme Court of the Russian Federation recognized such guidance in courts' verdicts as unfounded since they are not included in the list of aggravating circumstances of paragraph 1 of Article 63 of the Criminal Code of the Russian Federation.

Reasons for selecting the type and size of the punishment in the verdict of the court are very important. According to the Article 307 of the Criminal Procedure Code of the Russian Federation a descriptive-motivational part of the indictment must contain an indication of the circumstances mitigating and aggravating the punishment (paragraph 3, part 1) and the motives of the decision of all questions relating to the appointment of criminal penalties (paragraph 4 of the 1).

The reasons for sentencing should be specific and not formal or general in nature as it sometimes occurs in the jurisprudence (Ishchenko, 2002). It is impossible to accept the following reasoning satisfying in the court sentence: "in selection of punishment the court takes into account the severity of the crime and the perpetrator's personality", "the severity and nature of the committed crime, as well as the information characterizing the personality", "the high degree of a social danger of the crime, the degree of guilt and data characterizing personality", etc. They are too generic and does not meet the principle of punishment individualization. However, when choosing the punishment in judicial practice it can be often found a literal statement of the rules of Part 3 of Article 60 of the Criminal Code of the Russian Federation in the verdict without revealing their content (Stanovsky, 1999).

The reasons for the punishment in this form without specifying these circumstances in general terms does not answer the question, which of these circumstances and to which extent were taken into account by the court in sentencing.

The Plenum of the Supreme Court paid attention to this fact in its decision № 1 "On the court verdict" dated by 29.04.1996. It is necessary to motivate the court's findings concerning the qualification of the crime on a particular article of the criminal law, part of an item. Recognizing the defendant guilty of committing the crime on the grounds related to the evaluation categories, the court should not be limited reference to the relevant sign and must bring in a narrative verdict the circumstances giving rise to the conclusion that the crime contains this feature.

The courts should not appointment a sentence which in its size is manifestly unfair both because of softness and because of the severity. According to the law, the court in sentencing must take into account the nature and degree of social danger of the crime, the perpetrator's personality and the circumstances mitigating and aggravating the responsibility. Based on this, the sentence must specify what circumstances affecting the degree and nature of the liability of the defendant and other circumstances that characterize his personality were proven in the proceedings of the criminal case and were taken into account by the court in sentencing.

In motivation of selection of the type and size of penalties for aggravating circumstances the court must give the legal wording provided in the relevant paragraphs of Part 1 of Article 63 of the Criminal Code of the Russian Federation, with the concretization of the necessary reference to the case.

However, approximately in $7 \%$ of the investigated criminal cases the aggravating circumstances were cited in the court verdict in the wording that was not consistent with Article 63 of the Criminal Code of the Russian Federation (Gorbunova, 2004).

The need to define is more obvious in the fact that a number of aggravating circumstances are described in the law in the generalized form (for example, occurrence of serious consequences as a result of the crime).

The court is entitled to invoke in the verdict as a motive for the election of their specific penalties only such circumstances that are investigated and confirmed at the hearing. Under paragraph 6 of Part 1 of Article 73 of the Criminal Procedure Code of the Russian Federation each aggravating circumstance is a matter of proof at the hearing. And only on a condition that these circumstances will be substantiated, they can be the basis for sentencing and can be included in the motivation of the sentence.

So that none of the parties of the criminal proceedings has no doubts in the accuracy and correctness of recognizing the facts of the case as an aggravating circumstance under part 1 of Article 63 of the Criminal Code of the Russian Federation, the court should not only correctly describe the aggravating circumstance in the formulation of an aggravating circumstance set out in Article 63 of the Criminal Code of the Russian Federation, not only to name the 
article and establishes a list of aggravating circumstances, but also to refer to the list of the criminal case, which contains information confirming the existence of the circumstances to which the court draws attention in sentencing.

The particular importance is given to aggravating circumstances in a special order of the judgment provided by Articles 314-317 of the Criminal Procedure Code of the Russian Federation.

During the trial in a special order the judge does not conduct the general research and evaluation of the evidences gathered in the criminal case. But the circumstances characterizing the personality of the defendant and the aggravating circumstances can be investigated.

Thus, in that process the aggravating circumstances together with the data about the guilt's personality will play a decisive role in the election of a particular type and size of punishment to the defendant.

In imposing the sentence the court must take into account all aggravating circumstances established in the hearing of the case.

The exception to the above rule may be the cases where the defendant is plead guilty but deserving of leniency by the jury verdict. In reaching this verdict in accordance with Part 4 of Article 65 of the Criminal Code the court imposing the punishment can not take into an account the aggravating circumstances provided by the part 1 of the Article 63 of the Criminal Code of the Russian Federation.

In all other cases the court must indicate the presence of the aggravating circumstances and designate a stricter punishment.

The law directs the court on the need to consider all the circumstances in their totality that determines the location and value of each of them in a criminal case and the impact on the election of penalties. But the criminal law does not provide the accounting for the above-mentioned criteria. Meanwhile, it would be useful for the judges to know how each criterion assigns an impact on the punishment and how should their significance be assessed in relation to each other.

\section{Discussions}

In order to avoid a broad interpretation of the aggravating circumstances circle, it is appropriate to legislate in Article 63 of the Criminal Code the provision stating that the list of aggravating circumstances is exhaustive. The court is not entitled in its sentence to refer to the facts or evidences which are not set in paragraph 1 of article 63 of the Criminal Code of the Russian Federation as to aggravating circumstances. Such provisions exist in the criminal codes of some countries of the Commonwealth of Independent States.

The court in sentencing should point out available aggravating circumstances for a specific criminal case provided in article 63 of the Criminal Code of the Russian Federation. And separately to consider their impact on the choice of the type and size of a criminal punishment. We have studied the 1000 convictions in which the court set the account of aggravating circumstances (Gorbunova, 2004). An analysis of the court practice revealed that judges mixed these circumstances with other means of individualization of punishment listed in part 3 of article 60 of the Criminal Code of the Russian Federation, giving any circumstances of the case an aggravating sign at their discretion.

With regard to the aggravating circumstance the legislator does not define the criteria for their influence on the assigned punishment that appear to be necessary to recognize the existing lack of Russian criminal law. For example, article 61 of the Italian Penal Code provides the general aggravating circumstances the list of which is exhaustive. The presence of one aggravating circumstance entails a mandatory increase in the sentence by one-third but the term of imprisonment can not exceed 30 years.

Adding to the Russian criminal law the provisions containing the criteria for the influence of aggravating circumstances on the assigned punishment balances the accounting rules of certain mitigating circumstances provided in article 62 of the Criminal Code of the Russian Federation. And wit ill contribute to the purpose of fair punishment in accordance with article 6 of the Criminal Code of the Russian Federation.

A number of additions of the Criminal Code of the Russian Federation we have proposed earlier in the published monograph (Gorbunova, 2004).

\section{Conclusion}

Thus, the distinction of the aggravating circumstances referred in article 63 of the Criminal Code of the Russian Federation and the aggravating circumstances of the crimes provided in the Special Part of the Criminal Code of the Russian Federation can be considered deliberate. Moreover, the legislator gives various legal functions to the reviewed circumstances which excludes the possibility of their unification. Therefore, the attempts to link them together in the theory of criminal law and even unifying them have no practical meaning. A close resemblance to the names of the 
aggravating circumstance and qualifying circumstances of the crimes does not indicate the identity of their role, meaning and the essence of the legal phenomena.

The qualifying signs are characterized by a measure of influence on the character and degree of social danger of the crime. The presence of even one of such indication recognized as sufficient for the emergence of a new structure of a crime has a much greater degree of public danger than the composition without this aggravating circumstance, and, consequently, a much greater volume of provided criminal liability.

In their turn, the aggravating circumstances serve to measure the individualization of criminal responsibility within the sanction of an article providing the punishment for a crime.

Each aggravating circumstance provided in paragraph 1 of article 63 of the Criminal Code of the Russian Federation should be taken into account by the court in sentencing. The court has no right to ignore an aggravating circumstance, or not to take it into account, or to recognize it irrelevant. An accounting of the aggravating circumstance is not a right but an obligation of the court in sentencing. The list of aggravating circumstances is exhaustive and not subject to broad interpretation. The calls of the theoreticians and practitioners to consider the list of aggravating circumstances as an open should be discarded as this may result in a violation of the principle of equality of citizens before the law and the courts depending on the personal preferences of a particular judge.

\section{References}

Anashkin, G. (1980). The circumstances mitigating and aggravating the responsibility. The Soviet justice. № 6.

Andreeva, L.A., \& Volzhenkin, B.V., \& Pinchuk, V.I. (1974). Qualified types of theft of socialist property. Leningrad.

Bazhanov, M.I. (1974). Mitigating and aggravating circumstances in sentencing. - In the book: Questions of State and Law. Moscow.

Baskakova, V.E., Gabdrahmanov F.V., Gorbunova L.V., Smirnov M.A. (2015). Criteria for the Classification of the Common Legal Consequences of Criminal Conviction. Review of European Studies, № 7 (8). DOI: 10.5539/res.v7n8p308

Buranov, G.K. (2002). Aggravating circumstance in criminal law of Russia. Author's Dissertation. Master of Sciences. Ulyanovsk.

Galperin, I.M., \& Minskaya, V.S., \& Oreshkina, T.Y. (1986). Criminal liability for the theft of personal property from the entry into a home. Moscow, The circumstances aggravating the punishment under criminal law in Russia (theory and practice). Kazan.

Isaev, M.M. (1948). Criminal law. The general part. Moscow.

Ishchenko, A.V. (2002). Sentencing under the Criminal Code of the Russian Federation. Scientific and practical guide. Moscow.

Demidov, Y. (1964). Imputation of aggravating circumstances of the crime. Socialist legality, № 6.

Karpets, I.I. (1959). Aggravating and mitigating circumstances in the Soviet criminal law. Moscow.

Klenova, T.V. (2001). Russian criminal law: the nature, the history of formation, especially of lawmaking: Tutorial. Samara.

Kostareva, T.A. (1993). Qualifying circumstances in criminal law. Yaroslavl.

Kruglikov, L.L. (1977). Mitigating and aggravating circumstances in the Soviet criminal law. Yaroslavl.

Melnikov, Y.B. (1989). Differentiation of responsibility and individualization of punishment. Krasnoyarsk.

Mikhlin, A.S., Shlikov S.A. (1958). The circumstances aggravating and mitigating the criminal responsibility. The Soviet state and the right, № 8.

Stanovsky, M.N. (1999). Sentencing. St. Petersburg.

Tkachenko, V. (1997). General principles of sentencing. The Russian justice, № 1.

Fatkullin, F.I. (1974). Common problems of procedural evidence. Kazan. 
ISSN 2039-2117 (online) ISSN 2039-9340 (print)
Mediterranean Journal of Social Sciences MCSER Publishing, Rome-Italy
Vol 6 No 3 S7

June 2015 